\title{
Reading strategies for the profoundly deaf Libras users: Benefits of speech and lip reading for strengthening linguistic skills
}

\section{Estratégias de leitura em surdos profundos usuários da Libras: benefícios da oralização e da leitura labial para o fortalecimento de habilidades linguísticas}

\author{
Ângela Maria Vieira PINHEIRO' ${ }^{1}$ iD 0000-0002-5852-4320 \\ Andreia Chagas ROCHA-TOFFOLO² ID 0000-0002-8664-1663 \\ Douglas de Araújo VILHENA ${ }^{1}$ iD 0000-0003-2670-7963
}

\begin{abstract}
To understand the reading strategies used by deaf students, two groups of profoundly deaf individuals were tested: Group 1: users of the Brazilian Sign Language and Group 2: users of the Brazilian Sign Language and speech and/or lip reading. A reading test was used to assess the degree of development of logographic, alphabetic and orthographic strategies. The group of deaf students who used alternative means of communication (Group 2) showed improved performance in all psycholinguistic categories of the test in comparison to Group 1. It was observed that the use of phonology is not directly associated with good reading skills in the profoundly deaf. On the other hand, word recognition by these readers occurs via the utilization of the orthographic strategy, which proved to be efficient.
\end{abstract}

Keywords: Deafness; Lip reading; Reading; Sign language; Speech; Special education.

$\nabla \nabla v$

${ }^{1}$ Universidade Federal de Minas Gerais, Programa de Pós-Graduação em Psicologia: Cognição e Comportamento, Laboratório de Processos Cognitivos. Belo Horizonte, MG, Brasil.

2 Universidade Federal de Ouro Preto, Instituto de Ciências Humanas e Sociais, Departamento de Letras. R. do Seminário, s/n., Centro, 35420-000, Mariana, MG, Brasil. Correspondence to: A.C. ROCHA-TOFFOLO E-mail: <andreiarocha@ufop.edu.br>.

Support: This study was financed in part by the Conselho Nacional de Desenvolvimento Científico e Tecnológico (Process nº 134357/2013-2) and by the Coordenação de Aperfeiçoamento de Pessoal de Nivel Superior (Finance Code 001).

Article based on the dissertation of A.C. ROCHA-TOFFOLO, entitled "A leitura na surdez profunda: a influência da oralidade e da leitura labial e estratégias predominantes”. Universidade Federal de Minas Gerais, 2014.

$\boldsymbol{\nabla} \boldsymbol{\nabla} \boldsymbol{v}$

How to cite this article

Pinheiro, A. M. V., Rocha-Toffolo, A. C., \& Vilhena, D. A. (2020). Reading strategies for the profoundly deaf Libras users: Benefits of speech and lip reading for strengthening linguistic skills. Estudos de Psicologia (Campinas), 37, e190003. http://dx.doi.org/10.1590/1982-0 275202037e190003 


\section{Resumo}

Para compreender as estratégias de leitura utilizadas por indivíduos com surdez profunda, o presente estudo investigou dois grupos: Grupo 1, constituido por usuários da Libras - Língua Brasileira de Sinais; e Grupo 2, composto por indivíduos que, além da Libras, usam recursos de oralização elou leitura labial. Por meio do Teste de Competência de Leitura de Palavras, foi avaliado o grau de desenvolvimento das estratégias logográfica, alfabética e ortográfica. Em comparação ao Grupo 1, o grupo de surdos que utiliza meios alternativos de comunicação (Grupo 2) apresentou desempenho superior em todas as categorias psicolinguísticas do teste. Observou-se que o uso da fonologia não está diretamente associado à boa habilidade de leitura em surdos profundos e que o reconhecimento de palavras por esses leitores se dá por meio da utilização da estratégia ortográfica, que se mostrou eficiente.

Palavras-chave: Surdez; Leitura labial; Leitura; Línguas de sinais; Fala; Educação especial.

Since auditory experience is the sensory pathway that allows listeners to acquire the phonological representations necessary for learning the ability to identify written words, understanding the nature of proficient reading in deafness, particularly regarding the use of phonology by profoundly deaf readers, has become the object of studies. However, due to the lack of research consensus, Mayberry, Giudice, and Lieberman (2010) investigated in profoundly deaf individuals the relationship between the reading ability with both: Phonological Coding (i. e., mental representation of words based on acoustic properties) and Phonological Awareness. They concluded that Phonological Coding and Awareness, due their poor predictive power, is neither a robust phenomenon nor a sine qua non condition in the reading ability of individuals with severe and profound hearing loss.

According to Bélanger, Baum, and Mayberry (2012), the meaning of words is accessed from their orthographic representations during the reading process of the deaf, which tends to be strengthened with frequent exposure to printed material (Chamberlain \& Mayberry, 2008). Regarding the retention of written words in memory, in addition to speech-based coding for verbal materials (Baddeley, 2003), multiple codes can be used in accordance with the hypothesis of multiple coding by Hall and Bavelier (2010), which consist of orthographic, semantic and tactile codes or even the use of signs and manual spelling. This possibility reinforces the findings that the deaf can learn how to read if teaching is focused on consciously exploring orthographic cues (Almeida, Santos, \& Lacerda, 2015; Seimetz-Rodrigues \& Souza, 2016). As development models advocate, automatic word recognition based on well-specified orthographic codes is essential for the mastery of reading proficiency (Ehri, 2010).

F.C. Capovilla, Capovilla, Viggiano, Maurício, and Bidá (2005) analyzed the reading strategies of 740 deaf students aged 6 to 45 years from the $1^{\text {st }}$ grade of Elementary School to High School with mild to profound hearing loss. The instrument used was the Word Reading Competence Test (WRCT) (see section on instruments for the description of the test and full name of acronyms of the seven categories of stimuli that form the test), which assesses silent reading of isolated words, establishes the degree of development and preservation of logographic, alphabetic and orthographic strategies [for the definition of these strategies taking into account the level of orthographic depth, see Pinheiro and Scliar-Cabral (2018)]. The performance analysis of deaf students was compared with those of 1000 hearing students from the $1^{\text {st }}$ to $3^{\text {rd }}$ grades [mean score of deaf students from the $1^{\text {st }}$ grade (61.4) was equivalent to those of $3^{\text {rd }}$ grade hearing students (62.2)]. A distinct response pattern in the WRCT was found for each group: reading of deaf students [SIW (8.4) > SPW (8.0) > HPW (7.4) > PPS (6.5) > PVS (6.0)] and reading of hearing students [SPW (9.2) > SIW (8.8) > PVS (7.9) > PPS (6.9) > HPW (5.9)].

When comparing the two types of readers, four discrepancies were found: (I) HPW x PVS: deaf students, who used the visual word recognition strategy, were less likely to confuse homophonic pseudowords such as

2 "Aumossu" in instead of "Almoço" than hearing students and their score was higher in HPW than in PVS, 
unlike the hearing students, in which, for example, the pseudoword "Gaio" matched with a picture of a cat should be rejected; (II) PPS X PVS: deaf students made more mistakes in rejecting PVS, such as "Jacapé" instead of "Jacaré", and were more susceptible than hearing students to be mistaken by the visual similarity of these items; (III) HPW x PPS: hearing students scored lower on the HPW, since at the beginning of literacy instruction they tend to confuse homophonic words with phonological shifts such as "Jêlu" instead of "Gelo". Profoundly deaf students, who have not developed a phonological lexicon that allows them to check items with homophonic substitutions, tend to obtain better results in the HPW than in the PPS where the pseudoword "Ventilator" matched with a picture of a fan, for example, must be rejected; (IV) SIW x SPW: hearing students, when compared with deaf students, committed more errors in the SIW than in the SPW, whose stimuli produce unusual phonological forms when decoded such as "Catudo" matched with a picture of a sneaker. The semantically incorrect words still produce familiar phonological forms when decoded.

Although Capovilla et al. (2005) emphasize the difference in the pattern of deaf and hearing respondents in the SPW and SIW, deaf students answered $80 \%$ of the items correctly in each category. The word "Pazido" matched with a picture of syrup, for example, may be strange when pronounced, but it is not strange from an orthographic point of view because, although it is a pseudoword, it follows the orthographic structure of Portuguese, which makes it more difficult for the reader to reject it if the reader only relates it to the spelling of the word.

Capovilla et al. (2005) have made great contributions to the area. However, because their sample consists of individuals with different degrees of deafness, the study of reading strategies with a homogeneous group of deaf people becomes of interest. Thus, the aim of this research was to investigate the reading strategies in profoundly deaf users of Libras using the WRCT. The goal was to verify whether these strategies differed from a group of users of Libras in comparison with a group that used Libras in combination with speech and/or lip reading and whether these resources facilitate the reading process.

\section{Method}

\section{Participants}

The sample consisted of 37 students, $59.5 \%$ male, aged 12 to 18 years $(M=15.5 ; S D=1.7)$, from the $7^{\text {th }}$ grade to the $1^{\text {st }}$ year of high school from four institutions in Minas Gerais, São Paulo and Paraná. All students were profoundly deaf (self-report assessment), with no cochlear implants, and they were children of hearing parents.

The sample was divided into two groups: 16 (43\%) participants who were users of Libras (G1) and 21 (57\%) who used Libras in combination with speech and/or lip reading (G2). The two groups did not differ regarding the following: (I) nonverbal cognitive ability, assessed by the overall score of the Raven Progressive Matrices Scale, according to the Analysis of Covariance (ANCOVA) (covariates: school year, age, sex and school) of the raw score $(G 1: M=34.0 ; S D=8.2 ; G 2: M=37.0 ; S D=7.9)$ and the percentile $(G 1: M=31.1$; $S D=17.4 ; G 2: M=37.1 ; S D=19.3)\left[F_{(5.31)}<0.003 ; p<0.96\right]$; (II) chronological age (G1: $M=15.9 ; S D=1.7$; $\mathrm{G} 2: M=15.3 ; S D=1.4)\left[t_{(35)}=1.1 ; p=0.30\right] ;(I I I)$ school year $(\mathrm{G} 1: M=7.8 ; S D=0.8 ; G 2: M=8.1 ; S D=0.9)$ $\left[t_{(35)}=1.2 ; p=0.28\right] ;(\mathrm{IV})$ age at first contact with Libras (G1: $M=7.6$ years; $\left.S D=4.2 ; G 2: M=7.5 ; S D=3.2\right)$ $\left[t_{(35)}=0.1 ; p=0.88\right]$; and $(V)$ fluency in Libras, qualitatively assessed through an interview and during the test applications [for the complete description of this sample and assessments, including the description of instruments, see Rocha-Toffolo, Bernardino, Vilhena, and Pinheiro (2017)]. 


\section{Instruments}

The Word Reading Competence Test (WRCT) (Capovilla et al., 2005) assesses the silent reading of single words. The WRCT consists of 70 items grouped into seven categories of words and pseudowords, whose errors indicate specific difficulties. Each category has 10 items, each item matches a written word (or pseudoword) to a picture. The task of the participant is, from a spelling or semantic point of view, to circle the correct items and choose the incorrect items with an " $x$ ". Therefore, the picture-word pairs with regular and irregular correct words must be accepted, while semantically incorrect or pseudoword pairs must be rejected.

The categories, followed by the skills tested and an example of error, are as follows: (I) Semantically Incorrect Word (SIW): tests access to the semantic system (error: to choose the word "Train" matched with a picture of a "Bus" as correct); (II) Strange Pseudoword (SPW): tests the general reading ability and focused attention (error: to take the pseudowords "Pazido" and "Rassuno" as if they were words); (III) Homophonic Pseudoword (HPW): tests access to orthographic processing (error: to choose the pseudoword "Mininu" as correct instead of "Menino"; (IV) Pseudoword with Phonological Shift (PPS): tests access to the orthographic lexicon and difficulties in phonological processing (error: to choose the word "Ofelha" as correct instead of "Ovelha"); (V) Pseudoword with Visual Shift (PVS): tests the use of the logographic strategy (error: to choose the pseudoword "Papoue" as correct instead of "Parque"); (VI) Correct Regular Word (CRW): tests the general reading ability (error: not recognizing the word "Uva" (grape) or "Fada" (fairy)); and vii) Correct Irregular Word (CIW): tests the use orthographic processing or misspelling (error: not recognizing the word "Agasalho" (coat) or "Xadrez" (chess)). Errors denote the type of reading used and show possible failures in the learning process of the skill tested by the item. For example, failure to accept the CRW class and reject the SIW and HPW classes are an indication of orthographic processing problems. Failure to reject the PPS and PVS classes indicate phonological processing problems.

\section{Procedures}

The free and informed consent terms were signed by all participants and the study was approved by the Ethics Committee of the Universidade Federal de Minas Gerais (CAAE: 12548813.0.0000.5149). All students individually signed the consent term and the instruments were applied individually. The assessment was performed by two psychologists fluent in Libras during regular class time. Regarding the RPM results, we found good internal consistency (zero discrepancy) for participants, ensuring the reliability of the data collection.

Statistical analyses were performed using IBM ${ }^{\circledR}$ SPSS ${ }^{\circledR}$ Statistics (version 21.0) software at a significance level set to $5 \%$. The effect size (Cohen's d-value) determined the clinical difference of the differences so that the results equal to 0.2 were of small effect, 0.5 of moderate effect and greater than 0.8 were of large effect. To find outliers, the Outliers Labeling Rule technique was used at a value of $2.2 \mathrm{for} g$. Only a weighted score for WRCT for Group G2 was submitted to the Winsorizing process, i.e., its value was rounded to the nearest value.

\section{Results}

Age and WRCT. Pearson's bivariate analysis showed a negative but weak correlation between student's age and weighted scores for WRCT $(r=-0.347, p=0.036)$. Regarding test performance, 12 -year-old students, who were in the correct school year according to their age, obtained the best results $(M=64 ; S D=2.8)$ and those above the age of 18 years obtained the worst results $(M=49 ; S D=4.1)$. 
Level of education and WRCT. The total raw scores adjusted by Multiple Covariance Analysis, using school, gender and age, and respective means per sample as covariates are shown in Figure 1. Bonferroni's pair comparison test in the overall sample ( $G 1$ and $G 2$ together) showed that students in the $1^{\text {st }}$ grade presented better reading performance than those in the $7^{\text {th }}$ grade $(p=0.018 ; d=2.36)$ and $9^{\text {th }}$ grade $(p=0.032 ; d=3.30)$, but only slightly better than those in the 8 th grade $(p=0.076 ; d=1.71)$. No significant differences were found among the students in the $7^{\text {th }}$, 8th and 9th grades $(p=1.0)$. A similar pattern was found by Capovilla et al. (2005): $1^{\text {st }}$ graders were better than all the other students, but similar mean values (minimum score of 54 and maximum of 57 points, with only 3 points of amplitude) were found for students in other grades (from $7^{\text {th }}$ to $9^{\text {th }}$ grade). The same intragroup comparison for $\mathrm{G} 1$ and $\mathrm{G} 2$ showed no significant differences among raw scores of all school years (in G1 there were no students in the first year of high school). Taken together, the indistinctness of WRCT scores from the 6th grade onwards indicates low variability among the instrument's scores in more advanced school years.

$\mathrm{G} 1$ versus $\mathrm{G} 2$. In the mean raw score per sample in the WRCT, we found that the $\mathrm{G} 2$ participants showed better performance $(M=61.5 ; S D=6.8)$ in word reading when compared with those in $G 1(M=51.0$; $S D=4.7)\left[F_{(1,30)}=18 ; p=0.0002 ; d=1.80\right.$; the difference occurred even when sociodemographic and developmental characteristics were controlled] and with the deaf group in the study by Capovilla et al. (2005) $(M=58)\left[F_{(1,30)}=18 ; p=0.0002 ; d=1.80\right]$. The mean of the general sample $(\mathrm{G} 1+\mathrm{G} 2)$ was 57.0 with a standard deviation of 7.9 .

Logographic, phonological and orthographic processing. Multiple Covariance Analysis was used to distinguish the processes in which the covariates were school, school year, sex and age and the dependent variables of the five WRCT categories studied by Capovilla et al. (2005). As shown in Figure 2, except for G2, the response pattern of $\mathrm{G} 1$ and the deaf and hearing sample of the reference study was the same as predicted by the authors. The last two deaf groups showed similar mean performance (6.98 and 7.26, respectively), with lower PVS scores than in other samples and categories, which shows the students' difficulty in correctly

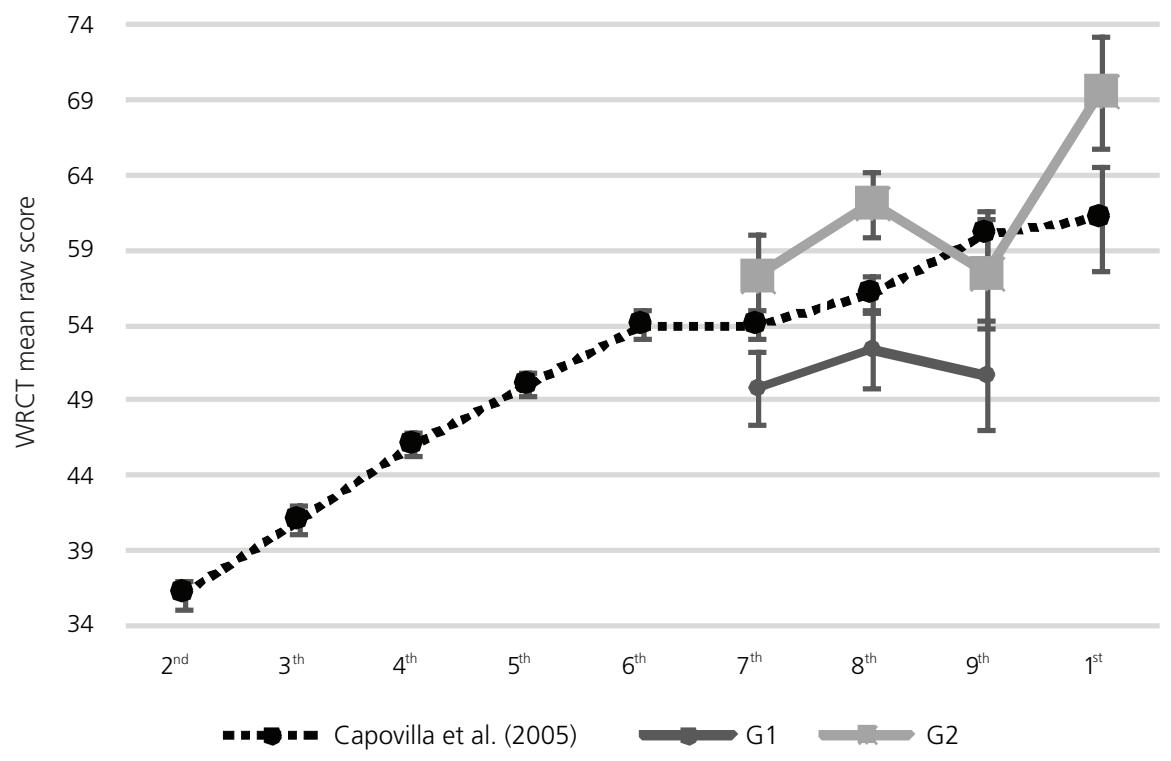

Figure 1. Mean raw score in the WRCT (Standard Error Bar), per school year, in the sample of this article and Capovilla's (2005).

Note: When comparing the articles, the school grades in the study by Capovilla et al. (2005) were converted to the current nine-year school system. WRCT: Word Reading Competence Test. 


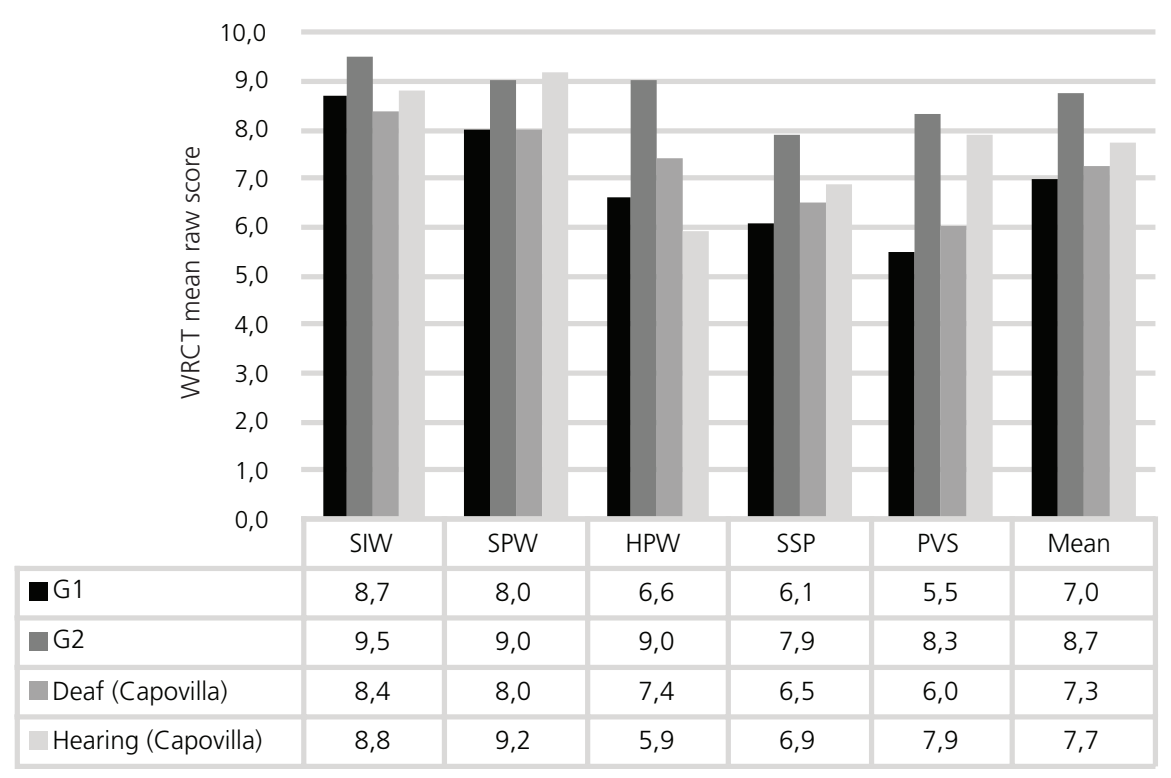

Figure 2. Pattern of mean correct answers by category in the WRCT and means in the sample of this article and Capovilla's et al. (2005).

Note: HPW: Homophonic Pseudowords; PPS: Pseudoword With Phonological Shift; PVS: Pseudowords With Visual Shift; SIW: Semantically Incorrect Words; SPW: Strange Pseudowords; WRCT: Word Reading Competence Test.

rejecting pseudowords with visual shifts. In a different way, we can say that the skills measured by the SIW and SPW categories are better established (with a score of 8 points or higher) and the skills measured by the HPW, PPS and PVS categories are more impoverished in these groups. In terms of the WRCT mean, G1 and the deaf group in the reference study differed from $\mathrm{G} 2$ and the group of listeners from the same reference study.

As for the response pattern of $\mathrm{G} 2$, which is the group of deaf people who presented the most different means of communication, they presented better reading skills than all other samples, including the listeners in Capovilla et al. (2005), with an mean performance of 8.74 points (except performance of $G 2$ and the sample of listeners in the SPW category, whose mean of correct answers did not differ in the two groups). G2 achieved the highest score for all samples in the PVS category (8.3 points), while G1 obtained the lowest rate of correct answers (5.5).

For the purpose of comparing our results with those in the study by Capovilla et al. (2005), we did not include the analysis of the categories of Regular Correct Words (CRW) and Irregular Correct Words (CIW). However, G1 and G2 did not differ significantly, as both CRW and CIW can be considered consolidated skills in both groups of readers, as they exceeded 8 points, as follows: G1: CIW (8.1) and CRW (8.6); G2: CIW (8.5) and CRW (8.5).

\section{Discussion}

We found that the older students in the present study sample presented the worst reading performance, which seems to result from the changes in the teaching approaches for the deaf in recent years. Although the bilingual education proposal, which considers Libras as the first language (L1) of the deaf person and written Portuguese as their second language (L2), has had legal support in Brazil since December 2005 (Law No. 5626), most students were part of the transition phase of the different models of education: oralism (approach focused on integrating the deaf into the hearing community, emphasizing the oral language of the country), bimodality (approach that uses speech and some signs concomitantly) and bilingualism. 
Another point taken into consideration was that, after 2005, due to the law, deaf adults began to be part of the school staff, either as instructors, teachers, technical or administrative staff, or in many cases, as Libras teachers (formally or informally) who taught students and teachers. This allowed younger students to have more direct contact with the sign language than older students due to greater interaction with deaf adult Libras users. When bilingualism was adopted in schools, sign language became the language of instruction, a common language, and no longer the 'villainous language', which used to be used at break time in secrecy. The older students might have acquired the language earlier, but they had no opportunity to practice it as the younger ones have today.

A striking factor of the investigated population refers to the school gap. We found that 26 students (70\%) were behind in their grade level according to their age. The difficulty of older students in reading may be due to their school delay, as they had been retained in the grade and showed no significant improvement in their language performance. Another explanation is related to the students' first contact with Libras. None of them had had contact with Libras before the age of 2 years, $61 \%$ had their first contact between the ages of 2 and 7 years, and the others (39\%) only had contact after the age of 8 .

\section{Reading processing}

The present research used the WRCT to investigate the reading strategies of profoundly deaf individuals, users of Libras, and determine if these strategies differ according to the use of speech and/or lip reading as a complement to Libras and if using these resources are an advantage that facilitates the strategies.

In general terms (performance pattern and use of strategies), the results of the present study did not differ from those of Capovilla et al. (2005), whose research was conducted with a heterogeneous sample (individuals with different degrees of deafness), and the task applied was considered valid, despite its limitations. At the same time, the analysis of the WRCT categories, as discussed below, shows the relevance of this study in assessing a less heterogeneous group, such as G1 and G2.

Semantically Incorrect Words (SIW) and Strange Pseudowords (SPW): Stimuli from both categories were correctly rejected by participants in G1 and G2 as the deaf participants in Capovilla et al. (2005), which shows that limited access to the semantic system and serious reading problems did not occur in any of the samples in our study.

Homophonic Pseudowords (HPW): The performance of G1 in this category was close to that of the deaf group used as reference, and both groups fared better than the group of listeners, who, because they used a phonological strategy, were confused with the phonological shifts. Only the readers in G2 correctly rejected the items in this category, which shows good performance of skills that involve orthographic reading strategy.

Pseudoword with Phonological Shift and Pseudoword with Visual Shift: The difficulty of G1 participants in rejecting pseudoword with Phonological Shift (PPS) and Pseudowords with Visual Shift (PVS) shows, in principle, phonological processing problems. Because they do not activate phonological codes during word recognition, and they have difficulty in correctly accessing their spelling representations, which is a sign of logographic reading, these items were not easily rejected. Capovilla's et al. (2005) explanation for the improved reading performance of these items is that only oralized deaf individuals - profile of the deaf in G2 -, can decode what they have read. Thus, it allows them to compare the phonological forms stored in their lexicon with the unusual phonological forms in the pseudowords.

However, Bélanger et al. (2012) claim that the activation of phonological codes is impossible by the profoundly deaf during reading. According to these authors, what is interpreted as sensitivity to phonological characteristics of stimuli in some studies may be a strategy in which the orthographic overlap is being used to accurately perform the task. 
Since spelling and phonology can be confused in the reading process, refined methods that clearly evaluate the word identification process are extremely relevant. Hagiliassis, Pratt, and Johnston (2005) discusses the degree of influence on orthographic operations during tasks used to assess phonological processing and the degree of influence on phonological operations during tasks used to assess orthographic processing. Negleting of these influences means that many researchers are using a specific task assuming that it is a pure measure of phonological or orthographic processing when it is not. This issue is directly related to the notion of testing or test combinations, which are optimal measures of the phonological and orthographic processing skills as well as the notion of pure psychological testing, that is, a test that measures a specific cognitive process as most precisely as possible without involving undesirable cognitive operations (Tunmer \& Nesdale, 1995).

In the same line, Bélanger et al. (2012) used the masked priming paradigm to investigate the effects of orthographic and phonological codes during word processing and estimated the contribution of each code during the reading process of skilled and less skilled deaf readers. This paradigm is a methodological resource that can provide a more consistent test of phonological effects than the effects usually found in lexical decision tasks. In these tasks, participants are presented with a list of randomly displayed real words and pseudowords. Their task is to press a certain key for the first group of stimuli and a different key for the second group. Therefore, it involves deciding whether the stimulus is a real word or a pseudoword.

In this case, according to the dual-route model of reading, the functionality of the phonological strategy is inferred by the ability to read pseudowords, while the functionality of the orthographic strategy is mainly demonstrated by the performance in reading real irregular words. Using masked priming, on the one hand, makes the distinction between phonologically or orthographically resembled words possible and, on the other, those that are not related to any of these aspects. The processing of information stored in memory is facilitated by the presentation of a prime, i.e., a previous stimulus (Foster, 1999).

In the experiment conducted by Bélanger et al. (2012), prime pseudowords were used as distractors to make the test less predictable. Four combinations were presented to participants: (I) similar orthographic and phonological words (e.g., bore and BORD); (II) similar phonological but different orthographic words (e.g., baur and BORD); (III) words that have no phonological and orthographic similarity (e.g., boin and BORD) and (IV) words that have no relation to each other, and they are written and spoken in completely different ways (e.g., clat and BORD).

Orthographic processing was measured by comparing categories 1 and 2, as phonological overlap is constant and orthographic overlap is modulated between these conditions. Phonological processing was measured by comparing categories 2 and 3, in which orthographic overlap is constant and phonological overlap is modulated between these conditions.

Masked priming paradigm was combined with short Stimulus-Onset Asynchronies (SOA) - prime exposure time -, in the lexical decision task to assess initial and automatic involvement of orthographic and phonological codes during word processing. The task was based on the Bimodal Interactive Activation Model, which proposes that orthographic codes are activated from 20 to 30 milliseconds (ms) before phonological codes (Grainger \& Holcomb (2009) for review). Participants were tested at $40 \mathrm{~ms}$ and $60 \mathrm{~ms}$, with an interval of 10 to 15 days between sessions. The analysis of $40 \mathrm{~ms}$ and $60 \mathrm{~ms}$ only showed a significant difference for orthographic interactions and no significance for the phonological prime.

The results of Bélanger et al. (2012) have suggested that both the most and less skilled deaf readers process information through the activation of orthographic codes - just as listeners do -, but they do not use phonological codes in the initial processing of words, which differs from the hearing readers. Since no differences were found between the two groups of deaf individuals (skilled and less skilled readers) regarding the use of phonological codes in word recognition, the authors concluded that phonological processing is not essential for proficient reading in profoundly deaf people. 
In G2, no problems were detected in the correct rejection of PVS and PPS. Participants in this group presented a higher ratio of correct answers in both categories when compared with participants in G1 and the deaf individuals in Capovilla et al. (2005). In the PPS, the performance of the group in question (G2) was even better than that of the listeners (means of 7.9 and 6.9, respectively) (Figure 2). According to what has been discussed so far, success in identifying the categories of pseudowords may have been influenced by orthographic information, which shows that it is better established in this group than in the other two groups of deaf individuals (G1 and deaf individuals in Capovilla et al. (2005)).

Since the difference between $G 2$ and $G 1$ is the use of Libras in combination with speech and/or lip reading (both groups are equivalent in cognitive ability, chronological age, age of exposure to Libras and fluency in Libras), it is of interest to investigate how and why these resources positively influence the performance of the tasks in question. The answer to these questions is beyond the scope of the present paper, since reliable results require sophisticated experimental designs using accurate measurements of speech and lip reading (in addition to Libras proficiency) as well as phonological and orthographic processes of reading. In this case, positive and significant correlations between speech and/or lip reading with the phonological or orthographic reading processes would, in fact, have a psychological reality.

Thus, due to the exploratory nature of the present study, we can raise two hypotheses from the results. At least two are possible. The first is that, in profoundly deaf individuals, the use of oralism and lip reading (or both) induce articulatory recognition of the word. That is, the movement of the lips during the pronunciation of a word, which seems to facilitate the memorization of the spelling patterns, since it is as if the deaf individuals could see the words being spoken as they read. According to Capovilla (2015a, 2015b, 2018), these individuals, when they use speech, they tend to shift between graphemes whose visible mouth shapes are similar to each other. Thus, when comparing the deaf individuals who are only Libras signers, "speech visualization" seems to allow the oralized individuals and those who lip read to process information differently, which favors learning.

Another important point concerning "articulatory movement awareness" is that this ability might be confused with "phonological awareness" in many studies. A recent example of this is the research by Wang, Silvestri, and Jahromi (2018), who found an association between phonological abilities [measured by a nonverbal phoneme detection task by Koo, Crain, LaSasso, and Eden (2008)] and reading comprehension in profoundly deaf people. Wang et al. only discussed one item of this task, but it may be inferred that instead of the task offering "a direct indicator of phonological abilities" (p.447) it may have functioned as an indicator of participants" "articulatory awareness". As in the present study, Koo et al. (2008) compared oralized deaf individuals and "cued speech cuers" with American Sign Language (ASL) users and found that the former performed as well as the hearing controls.

Regarding the second hypothesis, which does not compete with the first one, but complements it, is the possibility that speech and lip reading would not be directly linked to the development of the phonological reading strategy. Probably the use of speech and lip reading strengthened the linguistic development of these readers, allowing them to recognize words and access their meaning through orthographic cues, which agrees with is the reading models developed for hearing children. These models focus more on language skills than on phonological skills, since good language skills are predictive of competent reading in both hearing and deaf children.

According to Catts, Hogan, and Adolf (2005) and Dickenson, McCabe, Anastasopoulos, PeisnerFeinberg, and Poe (2003), general language problems crucially affect both word recognition and reading comprehension, or even each of these domains in isolation. In the same line, Leach, Scarborough, and Rescorla (2003) and Souza, Weirich, and Procailo (2017) found that students with oral language disabilities also have reading difficulties. It has been shown that "linguistic comprehension" or "listening comprehension" (Kim \& Pilcher, 2016) predicted by cognitive and linguistic skills along with "word reading" (Foorman, Koon, Petscher, Mitchell, \& Truckenmiller, 2015; Kim, 2015; Kim, 2017; Kim \& Wagner, 2015) or the "morphology" factor (Kieffer, Petscher, Proctor, \& Silverman, 2017) contributes directly to reading comprehension. 
Taken together, the findings on the influence of language skills on reading comprehension are particularly relevant for deaf children who have limitations due to late language acquisition, which has an impact on the mastery of their lexical and syntactic systems (Chamberlain \& Mayberry, 2008) as well as the morphological system (Trussell \& Easterbrooks, 2017). It also has implications for the teaching of reading and increasing language resources of the deaf through alternative systems such as speech and lip reading. Thus, intervention efforts should focus on building a solid linguistic foundation and focus on word recognition with an emphasis on orthographic cues. Corroborating Bélanger et al. (2012), teaching deaf children should be global rather than simply focusing on phonological coding.

\section{Conclusion and Recommendations}

The performance of the deaf group using alternative means of communication (G2) was better in all psycholinguistic categories in the reading test than the group that only used Libras (G1) and the deaf group taken as reference, showing good word and pseudoword recognition skills. However, the improved performance of G2 was not observed in the use of different reading strategies, except for greater accuracy in the PVS category compared to the PPS, which indicates their preference for the orthographic strategy. The overall G2 mean performance was 10.5 points higher than the $\mathrm{G} 1$ mean, which indicates that access to multiple means of communication improves reading performance.

This finding has implications for the teaching of reading and the increase of language resources for the deaf through alternative systems such as speech and lip reading. Thus, intervention efforts should focus on building a solid linguistic foundation and focus on word recognition with an emphasis on orthographic cues. The implementation of these suggestions is imperative, since the proper way to promote the development of oral language and the learning of reading and writing for the deaf has been the subject of great debate in education.

Finally, as for the measurement of the reading processes, reinforcing what has already been discussed about pure psychological testing, researchers should identify undesirable cognitive operations when interpreting their results. In the case of the word reading competence test, the correct rejection of the word "Gaio" in the PVS category, for example, may have occurred due to orthographic and non-phonological information, since the spelling of the stimulus is similar to the word "Gato". The same can occur with the pairs "Crianqas/Crianças", "Jacapé/Jacaré", "Teleuisao/Televisão", among others. It is well known that items whose spelling pattern resembles real words can be read by analogy. Similarly, many studies that attribute "phonological awareness" to the deaf is in fact before "articulatory awareness".

Therefore, further research should focus on adopting an experimental design that allows the investigation of the role of speech and/or lip reading to increase reading proficiency of profoundly deaf individuals who are users of Libras, and researchers should dedicate themselves to the development and validation of Libras, speech and lip reading proficiency measures as well as phonological and orthographic processing measures, which is relevant for the reliability of studies and identification of reading strategies in all types of participants, particularly in profoundly deaf individuals.

\section{Contributors}

A.M.V. PINHEIRO supervised the project design and dissertation and participated in the writing of the manuscript in all phases of its development, except for data collection, which was only supervised. A.C. ROCHA-TOFFOLO participated in all phases of the study with outstanding performance in the practical part of the work and was responsible for data collection. D.A. VILHENA participated in all phases of the study, with emphasis on data analysis and the writing of results. 


\section{References}

Almeida, D. L., Santos, G. F. D., \& Lacerda, C. B. F. (2015). O ensino do português como segunda língua para surdos: estratégias didáticas. Revista Reflexão e Ação, 23(3), 30-57. http://dx.doi.org/10.17058/rea.v23i3.6033

Baddeley, A. D. (2003). Working memory and language: An overview. Journal Com. Disorders, 36, 189-208. http://dx.doi. org/10.1016/S0021-9924(03)00019-4

Bélanger, N. N., Baum, S. R., \& Mayberry, R. (2012). Reading difficulties in adult deaf readers of French: Phonological codes, not guilty! Scientific Studies of Reading, 16(3), 263-285. http://dx.doi.org/10.1080/10888438.2011.568555

Capovilla, F. C., Capovilla, A. G. S., Viggiano, K., Maurício, A., \& Bidá M. (2005). Processos logográfico, alfabéticos e lexicais na leitura silenciosa. Estudos de Psicologia, 10(1), 15-23. http://dx.doi.org/10.1590/S1413-294X2005000100003

Capovilla, F. C. (2015a). Nossa língua portuguesa: como avaliar o grau de cifrabilidade de qualquer palavra falada e o grau de decifrabilidade de qualquer palavra escrita nas normas lusitana e brasileira. In R. S. Pereira (Ed.), Abordagem Multidisciplinar da Aprendizagem (pp.481-503). Viseu: Editora QualConsoante.

Capovilla, F. C. (2015b). Paradigma matricial de linguagem oral, escrita e de sinais: taxonomia e sistema de variáveis para tratamento conceitual, experimental e estatístico. In F. H. Santos, V. Andrade, \& O. Bueno (Eds.), Neuropsicologia hoje (2a ed., pp.91-97). Porto Alegre: Artmed Editora.

Capovilla, F. C. (2018). Linguagem oral e escrita: paradigma, taxonomia e sistema de variáveis. In A. M. Soares, J. R. O. R. Simão \& L. M. Neves (Eds.), Caminhos da aprendizagem e inclusão: entretecendo múltiplos saberes (pp.103-124). Belo Horizonte: Artesã.

Catts, H. W., Hogan, T. P., \& Adolf, S. M. (2005). Developmental changes in reading and reading disabilities. In H. Catts \& A. Kamhi (Eds.), Connections between language and reading disabilities (pp.25-40). Mahwah: Erlbaum.

Chamberlain, C., \& Mayberry, R. (2008). American Sign Language syntactic and narrative comprehension in skilled and less skilled readers: Bilingual and bimodal evidence for the linguistic basis of reading. Applied Psycholinguistics, 29(3), 367-388. http://dx.doi.org/10.1017/S014271640808017X

Dickenson, D. K., McCabe, A. L., Anastasopoulos, L., Peisner-Feinberg, E. S., \& Poe, M. D (2003). The comprehensive language approach to early literacy: The inter relationships among vocabulary, phonological sensitivity, and print knowledge among preschool-aged children. Journal of Educational Psychology, 95, 465-481. http://dx.doi. org/10.1037/0022-0663.95.3.465

Ehri, L. C. (2010). Development of Sight Word Reading: Phases and Findings. In M. J. Snowling \& C. Hulme (Eds.), The science of reading: A handbook (pp.362-378). Oxford: Blackwell Publishing.

Foster, K. J. (1999). The microgenesisof priming effects in lexical access and spreading activation. Brain and Language, 68, 5-15.

Foorman, B. R., Koon, S., Petscher, Y., Mitchell, A., \& Truckenmiller, A. (2015). Examining general and specific factors in the dimensionality of oral language and reading in 4th and 10th grades. Journal of Educational Psychology, 107, 884-899. http://dx.doi.org/10.1037/edu0000026

Grainger, J., \& Holcomb, P. J. (2009). Watching the word go by: On the time-course of component processes in visual word recognition. Language and Linguistics Compass, 3(1), 128-156. http://dx.doi.org/10.1111/j.1749-818X.2008.00121.x

Hall, M., \& Bavelier, D. (2010). Working memory, deafness and sign language. In M. Marschark \& P. E. Spencer (Eds.). The handbook of deaf studies, language and education Oxford (pp.458-472). Oxford: Oxford University Press.

Hagiliassis, N., Pratt, C., \& Johnston, M. (2005). Orthographic and phonological processes in reading. Reading and Writing, 19(3), 1-29.

Kieffer, M. J., Petscher Y., Proctor, C. P., \& Silverman, R. D. (2017). Is the whole greater than the sum of its parts? Modeling the contributions of language comprehension skills to reading comprehension in the upper elementary grades. Scientific Studies of Reading, 20(6), 1-19. http://dx.doi.org/10.1080/10888438.2016.1214591

Kim, Y. S. G., \& Pilcher, H. (2016). What is listening comprehension and what does it take to improve listening comprehension? In R. Schiff \& M. Joshi (Eds.), Handbook of interventions in learning disabilities (pp.59-174). New York: Springer.

Kim, Y.-S. (2015). Language and cognitive predictors of text comprehension: Evidence from multivariate analysis. Child Development, 86, 128-144. http://dx.doi.org/10.1111/cdev.12293

Kim, Y.-S. (2017) Why the simple view of reading is not simplistic: Unpacking component skills of reading using a direct and indirect effect model of reading (DIER). Scientific Studies of Reading, 21(4), 310-333, http://dx.doi.org/10.1080/10 888438.2017.1291643 
Kim, Y.-S. G., \& Wagner, R. K. (2015). Text (Oral) reading fluency as a construct in reading development: An investigation of its mediating role for children from Grades 1 to 4 . Scientific Studies of Reading, 19, 224-242. http://dx.doi.org/1 $0.1080 / 10888438.2015 .1007375$

Koo, D., Crain, K., LaSasso, C., \& Eden, G. (2008). Phonological awareness and shortterm memory in hearing and deaf individuals of different communication backgrounds. Annals of the New York Academy of Science, 1145, 83-99. http://dx.doi.org/10.1196/annals.1416.025

Leach, J. M., Scarborough, H. S., \& Rescorla, L. (2003). A longitudinal investigation of reading outcomes in children with language impairments. Journal of Speech, Language, and Hearing Research, 45, 1142-1157.

Mayberry, R. I, Giudice, A. A. del, \& Lieberman, A. M. (2010). Reading achievement in relation to phonological coding and awareness in deaf readers: A meta-analysis. Journal of Deaf Studies and Deaf Education, 16(2), 164-188. http:// dx.doi.org/10.1093/deafed/enq049

Pinheiro, A. M. V., \& Scilar-Cabral, L. (2018). Dislexia: causas e consequências. Belo Horizonte: Editora UFMG.

Rocha-Toffolo, A. C., Bernardino, E. L. A., Vilhena, D. A., \& Pinheiro, A, M. V. (2017). Os benefícios da oralização e da leitura labial no desempenho de leitura de surdos profundos usuários da Libras. Revista Brasileira de Educação, 22(71). http://dx.doi.org/10.1590/S1413-24782017227165.

Seimetz-Rodrigues, C., \& Souza, A. C. (2016). Ensino da leitura a surdos: o conhecimento do objeto de ensino e suas implicações para a prática pedagógica. Linguagem \& Ensino, 19(1) 55-79.

Souza, A. C., Wirich, H. C., \& Procailo, L. (2017). A compreensão da argumentação linguística: hipótese de interação entre leitura e oralidade. Revista de Estudos da Linguagem, 25(2), 873-901. http://dx.doi.org/10.17851/22372083.25.2.873-901

Trussell, J. W., \& Easterbrooks, S. R. (2017). Morphological knowledge and students who are deaf or hard-of-hearing: A Review of the Literature. Communication Disorders Quarterly, 38(2) 67-77. http://dx. doi.org/10.1177\%2F1525740116644889

Tunmer, W. E., \& Nesdale, A. R. (1995). Phonemic segmentation skill and beginning reading. Journal of Educational Psychology, 77(4), 417-427. http://dx.doi/10.1037/0022-0663.77.4.417

Wang, Y., Silvestri, J. A., \& Jahromi, L. B. (2018). Selected factors in reading comprehension for deaf and hearing adults: Phonological Skills and Metacognition. American Annals of the Deaf 162(5), 445-462. http://dx.doi.org/10.1353/ aad.2018.0003

Received: January 28, 2019

Approved: September 11, 2019 